УДК 620.92

\title{
АНАЛІЗ ЕНЕРГЕТИЧНИХ СТРАТЕГІЙ КРАЇН ЄС ТА СВІТУ І РОЛІ В НИХ ВІДНОВЛЮВАНИХ ДЖЕРЕЛ ЕНЕРГІЇ. ЧАСТИНА 1
}

\author{
Гелетуха Г.Г., канд. тех. наук, Желєзна Т.А., канд. тех. наук, Баштовий А.І., канд. тех. наук \\ Інститут технічної теплофізики НАН Украӥни, вул. Желябова, 2а, Київ, 03680, Україна
}

\begin{abstract}
Розглянуто поточний стан та перспективи розвитку відновлюваної енергетики в світі та в Європейському Союзі. Проаналізовано існуючі енергетичні стратегії та прогнози розвитку енергетики до 2050 року. Показано необхідність скорочення загального споживання первинної енергії за рахунок широкого впровадження енергоефективних технологій та енергоощадних заходів.
\end{abstract}

Рассмотрено современное состояние и перспективы развития возобновляемой энергетики в мире и в Европейском Союзе. Проанализированы существующие энергетические стратегии и прогнозы развития энергетики до 2050 года. Показана необходимость сокращения общего потребления первичной энергии за счет широко внедрения энергоэффективных технологий и энергосберегающих мер.

Бібл. 9, табл. 1, рис. 6.

The paper covers state of the art and prospects for the development of renewable energy in the world and in the European Union. Available energy strategies and forecasts for the energy sector development until 2050 are analyzed. It is shown that it is necessary to reduce total consumption of primary energy by introducing energy efficient technologies and energy saving measures.

Ключові слова: відновлювані джерела енергії, відновлювана енергетика, кінцеве енергоспоживання, енергоефективність, парникові гази.

ВВП - валовий внутрішній продукт;

ВДЕ - відновлювані джерела енергії;

ЖКГ - житлово-комунальне господарство;

ЗППЕ - загальне постачання первинної енергії;

КСК - концентруючі сонячні колектори;

\section{Загроза глобального потепління}

3 ростом індустріального виробництва в світі зросла кількість викидів парникових газів в атмосферу, що, в свою чергу, призвело до глобальних змін клімату. Для запобігання цьому у 1997 році було прийнято Кіотській протокол, до якого (станом на листопад 2009 р.) приєднались 192 країни, відповідальні за 64 \% викидів парникових газів в світі. Незважаючи на зусилля багатьох країн з реалізації Кіотського протоколу, їх було недостатньо для запобігання глобальному потеплінню.

Міжнародне енергетичне агентство у 2012 році представило аналіз поточного стану розвитку світової енергетики, а також три сценарії зміни клімату до 2050 року, базуючись на різних стратегіях та пріоритетах в енергетичному
ОЕСР - Організація економічного співробітництва та розвитку;

ФЕ - фотоелектричні елементи;

н.е. - нафтовий еквівалент.

секторі [1]. Найпривабливішим та найбезпечнішим для нашої планети $є$ сценарій 2DS (підвищення середньорічної температури на $2{ }^{\circ} \mathrm{C}$ до 2050 року). Для втілення цього сценарію потрібні суттєві зміни в структурі глобальної енергетики, зокрема, обсяги викидів парникових газів до 2050 року мають скоротитися вдвічі у порівнянні з 2009 роком (рис. 1). Крім того, енергоємність світової економіки повинна постійно знижуватись, а споживання енергії зменшуватися (рис. 2).

У грудні 2015 р. на черговій зустрічі Конференції сторін Рамкової конвенції ООН про зміну клімату в Парижі 195 країн ухвалили текст нової кліматичної угоди, що започаткує нову еру глобальної боротьби зі зміною клімату на планеті. Головний здобуток угоди - 
домовленість країн, що не можна перевищувати рівень потепління більше ніж на $2{ }^{\circ} \mathrm{C}$. Також вони заявили, що докладуть максимальних зусиль, щоб не перевищити $1,5{ }^{\circ} \mathrm{C}$ потепління. Щоб цього досягти, країнам доведеться відмовлятись від викопного палива та переходити на відновлювані джерела енергії. Крім того, країни також погодилися стати вуглецево-нейтральними у другій половині цього століття. Це означає, що викиди парникових газів від людської діяльності не мають перевищувати їх поглинання екосистемами.

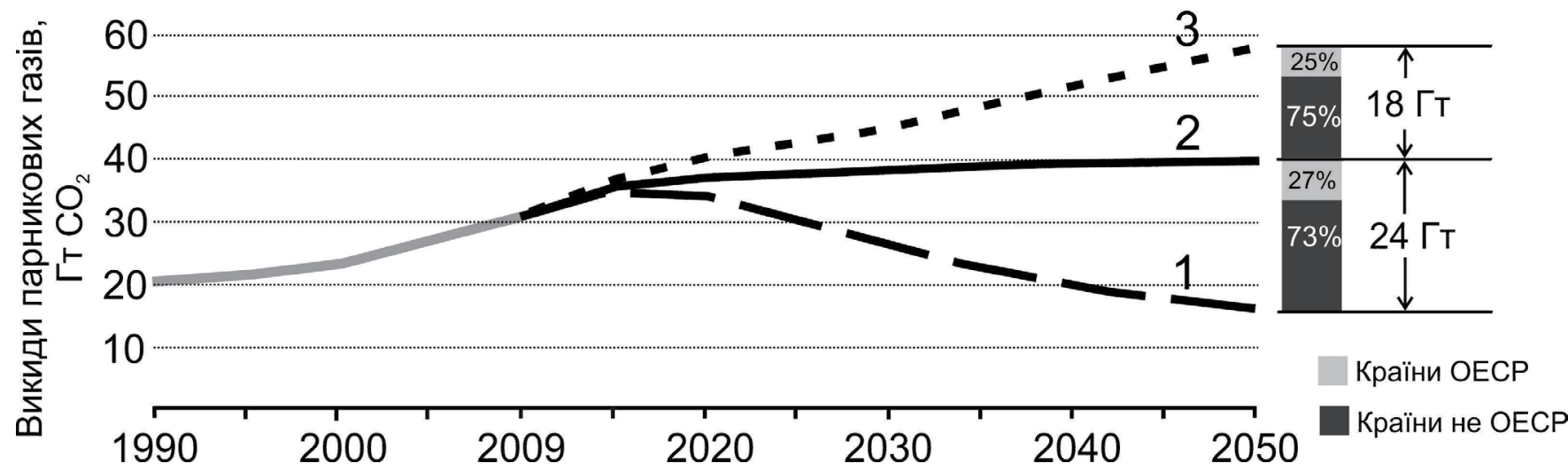

Рис. 1. Динаміка зміни обсягу викидів парникових газів у світовій енергетиці згідно трвом сценаріям зміни клімату планети [1].

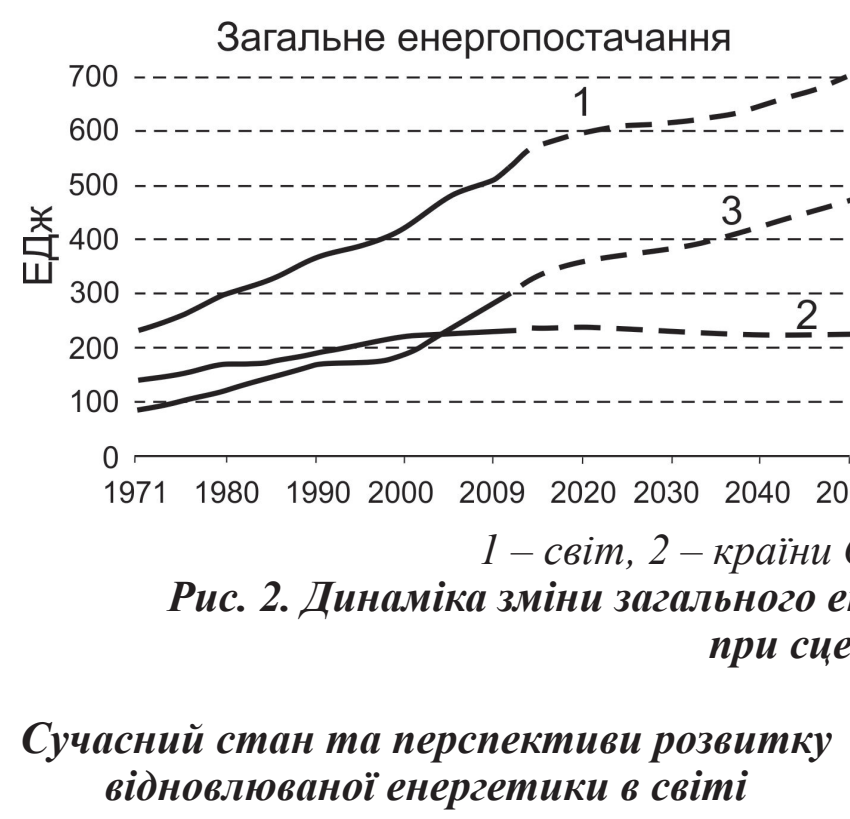

На сьогодні відновлювані джерела енергії забезпечують близько 19 \% кінцевого енергоспоживання в світі, зокрема традиційна біомаса - $9 \%$, сучасні ВДЕ - більше 10 \% (виробництво теплової та електричної енергії, транспортний сектор). Загалом за рахунок біомаси (традиційної та сучасної) покривається близько $14 \%$ кінцевого споживання енергії. Термін «традиційна біомаса» означає безпосереднє використання біомаси для приготування їжі та для обігріву у країнах, що розвиваються. Поняття «сучасні ВДЕ/біомаса» стосується використання ВДЕ/біомаси в сучасних технологіях виробництва енергії.

Внесок відновлюваних джерел енергії до загального виробництва електроенергії в світі становить майже $23 \%$, при цьому левова частка припадає на гідроенергію - 16,6 \%. 3 інших ВДЕ найбільша частка у вітроенергії - 3,1 \%, за якою слідує біомаса - 1,8 \%. Найкрупнішими виробниками «зеленої» електроенергії є 7 країн, сумарні потужності яких складають 71,5% світових (470 
ГВт, без врахування гідроенергіï): Китай, США, Німеччина, Італія, Іспанія, Японія, Індія (рис. 3) [2].

Теплова енергія становить близько половини кінцевого енергоспоживання в світі. Більше чверті потреби в тепловій енергії забезпечується за рахунок відновлюваних джерел, зокрема $17 \%$ дає традиційна біомаса, 7 \% - сучасна біомаса і лише $1 \%$ - інші сучасні ВДЕ.

Міжнародне Агентство 3 відновлюваної енергетики розробило Дорожню Карту для досягнення подвоєння частки відновлюваних джерел енергії у світовому споживанні енергії у період 2010...2030 pp. (REmap 2030): $318 \%$ ВДЕ у загальному кінцевому енергоспоживанні (2010 р.) до 36 \% (2030р.) [3]. При цьому сучасні відновлювані джерела енергії мають поступово витісняти використання традиційної біомаси. Оскільки у 2010 р. 318 \% ВДЕ половина припадала на традиційну біомасу, то у 2030 р. частка сучасних ВДЕ має більш ніж потроїтись (до 30 \%), залишаючи традиційному використанню біомаси лише $6 \%$ (рис. 4).
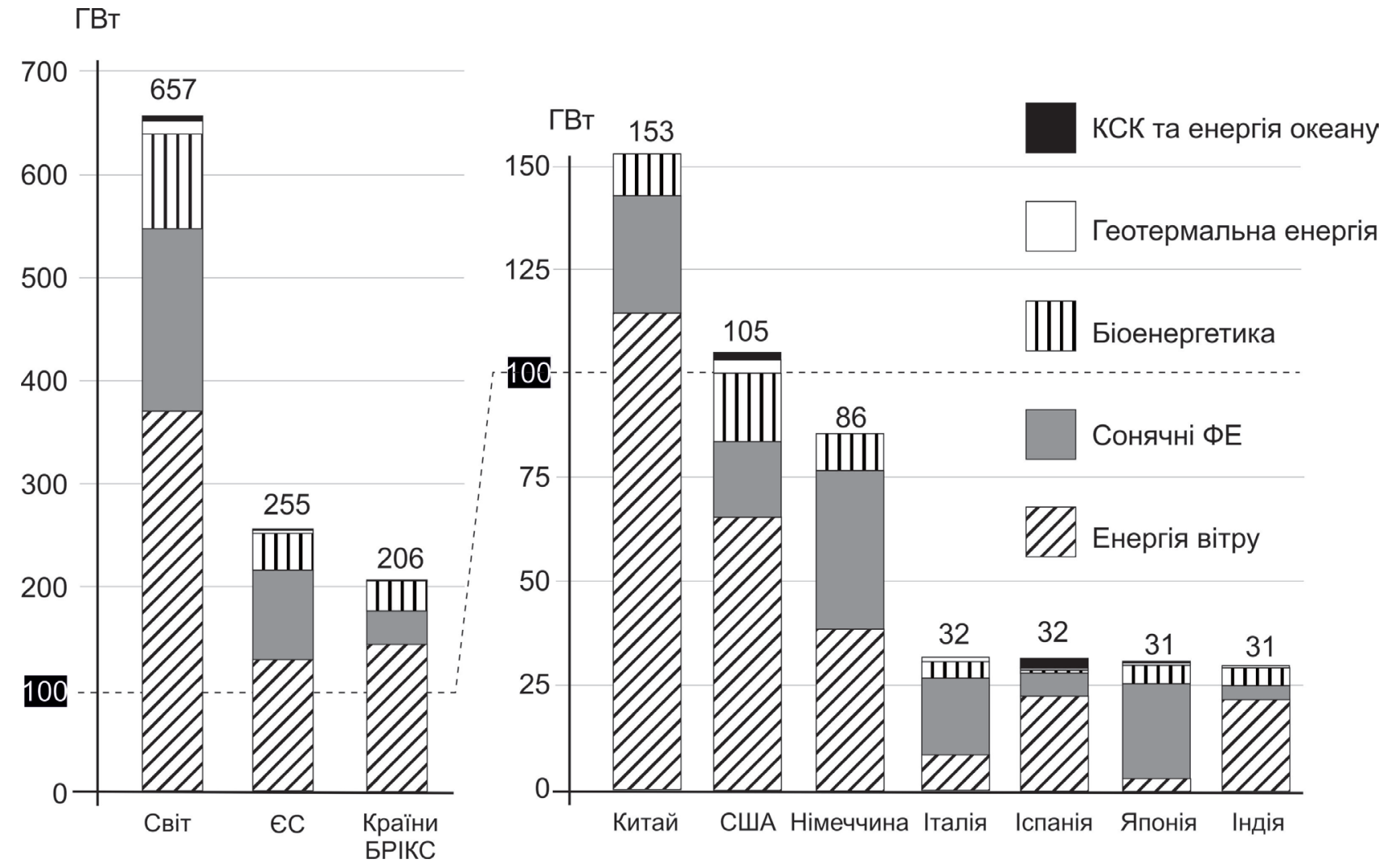

Рис. 3. Встановлена електрична потужність ВДЕ у світі без врахування гідроенергіï (2014 р.) [2].

Цікаво порівняти Дорожню Карту REmap 2030 з прогнозом Світової Енергетичної Ради, яка розробила два сценарії розвитку світової енергетики до 2050 року [4]. Сценарій 1 передбачає доволі повільний розвиток відновлюваної енергетики - $20 \%$ загального постачання первинної енергії у 2050 році та досить суттєве зростання ЗППЕ порівняно 32010 роком - на 38 \% (з 546 ЕДж/рік у 2010 р. до 879 ЕДж/рік у 2050 р.). Цей сценарій видається малореа- лістичним, оскільки його ціль 3 ВДЕ досягнуто вже зараз.

Сценарій $2 є$ більш реалістичним. Він передбачає переважний розвиток відновлюваної енергетики та зростання енергоефективності. Завдяки цьому у 2050 році частка ВДЕ має досягти близько $30 \%$ у ЗППЕ та $50 \%$ у виробництві електроенергії При цьому загальне постачання енергії у період 2010...2050 pp. зросте лише на $22 \%$. 


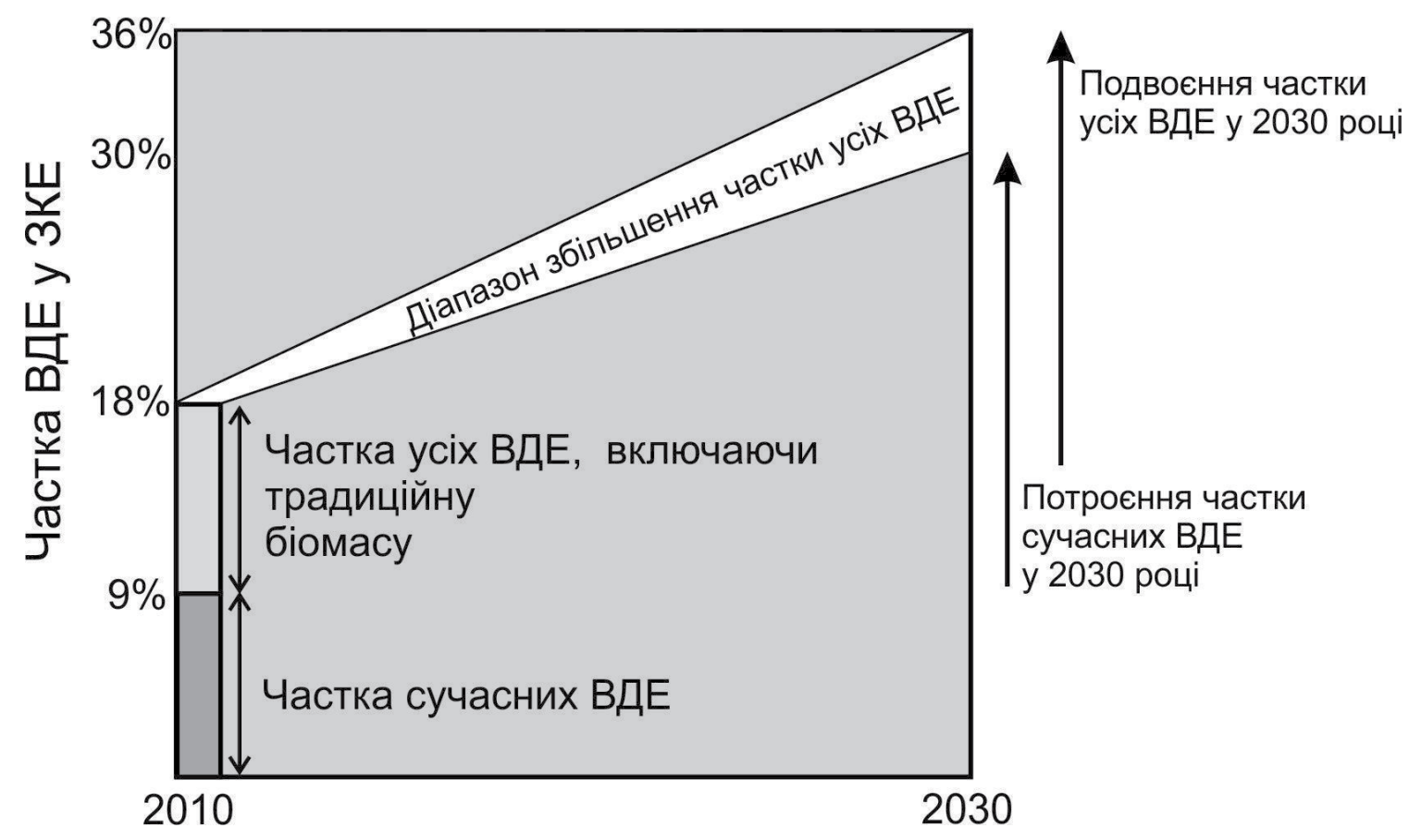

Рис. 4. Плани щцодо подвосння частки ВДЕ у загальному кінцевому енергоспоживанні світу згідно Дорожньої Карти REmap 2030 [3].

\section{Проекти по досягненню 100 \% споживання відновлюваної енергії}

На сьогоднішній день в світі нараховується близько 150 запланованих та вже реалізованих проектів із повного переходу на відновлювану енергетику. Вони поділяються на декілька категорій: міські, регіональні, державні, проекти у житловому фонді та у бізнесі. Серед таких проектів по окремих країнах, містах та компаніях можна виділити наступні [5]:

- Данія поставила за мету до 2035 р. досягти $100 \%$ виробництва теплової та електричної енергії з відновлюваних джерел та 100 \% енергї з ВДЕ в усіх секторах до 2050 р.

- В Ісландії вже досягнуто 100 \% виробництва електроенергії та 85 \% теплової енергії за рахунок ВДЕ.

- Шотландія: мета - 100 \% виробництва електроенергії та забезпечення 30 \% загальної потреби в енергії за рахунок ВДЕ до 2020 р.

- Мальдіви: мета - 100 \% енергії з ВДЕ до 2020 року.

- Коста-Ріка з початку 2015 року забезпечує потребу в електроенергії на 100 \% за рахунок ВДЕ. До 2020 року поставлено за мету до- сягти повної декарбонізації. Тут і далі «повна декарбонізація» або «100% скорочення викидів парникових газів» означає, що викиди парникових газів від людської діяльності не мають перевищувати їх поглинання екосистемами.

- Саудівська Аравія прийняла рішення до 2040 року повністю відмовитися від використання викопних палив й замінити їх відновлюваними джерелами енергії.

- Уряд Уругваю зробив офіційну заяву, що станом на грудень 2015 року 94,5 \% потреби країни в електроенергії забезпечується за рахунок відновлюваних джерел. До 2017 року планується знизити викиди вуглецю в атмосферу на $88 \%$ у порівнянні з середніми показниками 2009...2013 pp. й досягти повної декарбонізації до 2030 року.

- Три міста США (Аспен, Бурлінгтон, Вермонт) вже повністю перейшли на відновлювану енергетику. Міста Сан-Франциско, Пало-Альто, Сан-Дієго, Ітака, Грінсбург, Джорджтаун, Сан-Хосе також взяли за мету перехід на ВДЕ і вже мають прийняті відповідні програми.

- Ванкувер (Канада): у 2015 року були прийняті зобов'язання щодо переходу міста на 
$100 \%$ з ВДЕ.

- Франкфурт (Німеччина): запланована повна декарбонізація міста за рахунок ВДЕ та альтернативного автомобільного палива до 2050 року.

- Копенгаген (Данія): мета - до 2035 р. досягти 100 \% виробництва теплової та електричної енергії з відновлюваних джерел та $100 \%$ енергії з ВДЕ в усіх секторах до 2050 р. Повна декарбонізація міста запланована до 2025 року. Наразі вже 98 \% населення отримують теплову енергію 3 твердих побутових відходів та біомаси.

- Мюнхен (Німеччина): мета - $100 \%$ електроенергії з ВДЕ у житловому фонді до 2015 року та для всіх споживачів до 2025 року.

- Мальмо (Швеція): мета - 100\% відновлюваної електроенергії до 2020 року.

- Сідней (Австралія): мета - 100\% виробництва електроенергії, теплоти та холоду 3 ВДЕ до 2030 року.
До акції переходу на відновлювану енергетику підключились такі всесвітньо відомі бренди, як IKEA, Johnson \& Johnson, Nike, Procter \& Gamble, Starbucks, Voya Financial and Walmart, Google, Apple, Microsoft, Facebook, Virgin Group, RWE, E.ON та інші. За свою мету вони ставлять використання електроенергії виключно 3 відновлюваних джерел в усіх секторах своєї діяльності.

\section{Енергетичні стратегії Свропейського Союзу}

В Свропейському Союзі стан розвитку відновлюваної енергетики в цілому близький до загальносвітових показників. Внесок ВДЕ до кінцевого енергоспоживання складає майже $16 \%$ (табл. 1), в тому числі біомаси - більше $9 \%$. Частка ВДЕ у виробництві електроенергії становить 25,4 \%, зокрема 3 біомаси отримується близько $5 \%$. Більше 19 \% загального обсягу теплової енергії в СС виробляється з відновлюваних джерел, головним чином, з біомаси.

Табл. 1. Досягнуті та заплановані показники щодо частки ВДЕ у валовому кінцевому споживанні енергії в Свросоюзі (\%) [6]

\begin{tabular}{|l|c|c|l|c|c|}
\hline \multicolumn{1}{|c|}{ Країни СС } & 2014 & 2020 & Країни СC & 2014 & 2020 \\
\hline СС & 15,8 & 20 & Литва & $23,5^{*}$ & 23 \\
\hline Бельгія & 7,9 & 13 & Люксембург & 4,7 & 11 \\
\hline Болгарія & $20,2^{*}$ & 16 & Угорщина & 10,9 & 13 \\
\hline Чеська Республіка & $13,2^{*}$ & 13 & Мальта & 5,1 & 10 \\
\hline Данія & 28,5 & 30 & Нідерланди & 5,4 & 14 \\
\hline Німеччина & 13,8 & 18 & Австрія & 32,8 & 34 \\
\hline Естонія & $26,3^{*}$ & 25 & Польща & 11,5 & 15 \\
\hline Ірландія & 8,4 & 16 & Португалія & 26,5 & 31 \\
\hline Греція & 15,3 & 18 & Румунія & $24,5 *$ & 24 \\
\hline Іспанія & 15,8 & 20 & Словенія & 22,1 & 25 \\
\hline Франція & 14,5 & 23 & Словаччина & 12,0 & 14 \\
\hline Хорватія & 19,8 & 20 & Фінляндія & 37,9 & 38 \\
\hline Італія & $17,4 *$ & 17 & Швеція & $53,7 *$ & 49 \\
\hline Кіпр & 8,2 & 13 & Велика Британія & 6,7 & 15 \\
\hline Латвія & 36,1 & 40 & & & \\
\hline
\end{tabular}

* Країни, які вже перевищили свою офіційну мету 2020 року. 
Для досягнення мети 2020 року (20 \% ВДЕ у валовому кінцевому енергоспоживанні) країни ЄС мають не тільки нарощувати потужності відновлюваної енергетики, але й скорочувати споживання первинної енергії - загалом по ЄС-28 приблизно на $5 \%$ до 2020 р. порівняно 3 2013 р. (рис. 5).

Щоб дотриматись сценарію зміни клімату 2DS, у 2011 p. Євросоюз ще раз підтвердив свою офіційну мету по зниженню емісії парникових газів (декарбонізації) у 2050 році на $80 \ldots 95$ \% у порівнянні з показниками 1990 року (рис. 6) [8]. Оскільки сектор енергетики є одним 3 основних джерел викидів парникових газів, які пов'язані з діяльністю людини, то й головні резерви по зменшенню цих викидів мають бути знайдені і реалізовані саме в ньому. 3 огляду на це, Європейська Комісія розробила Дорожню Карту з енергетики до 2050 року [9], в якій проаналізувала, як саме можна досягти поставлених цілей по зниженню емісії парникових газів, забезпечуючи при цьому надійність та конкурентоспроможність систем енергопостачання.

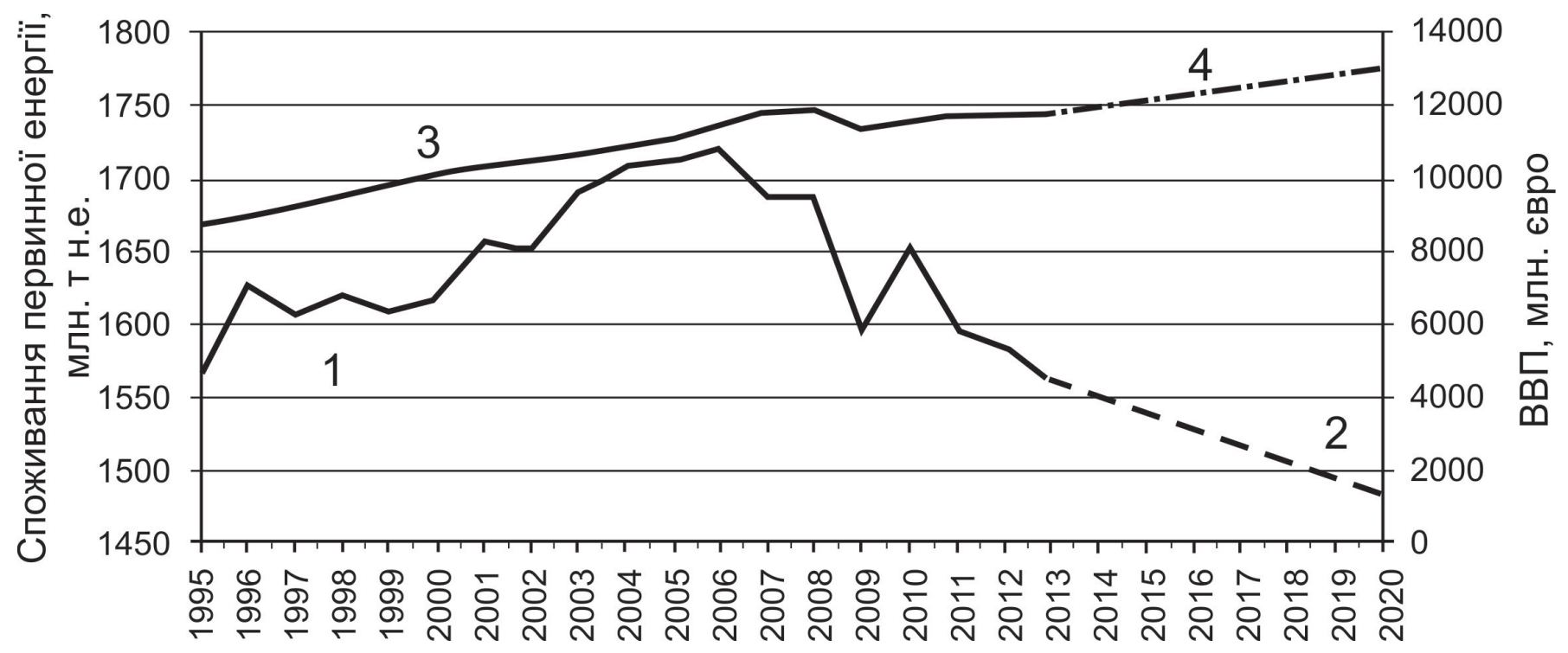

1, 2 - фактичне та прогнозоване споживання первинної енергії в $C$, відповідно, 3 - фактичний ВВП (при ринкових цінах 2005 р.), 4 - прогнозований ВВП (приріст 1,5\%)

Рис. 5. Динаміка споживання первинної енергї̈ та ВВП в СС-28 [7].

В Дорожній Карті ЄС розглянуто п’ять можливих сценаріїв розвитку енергетики (так звані сценарії декарбонізації). В основу кожного 3 них покладено одне 3 наступних припущень щодо того, яка саме тенденція буде превалювати в майбутньому в енергетичному секторі Свропейського Союзу (детальний аналіз даних п'яти сценаріїв розвитку представлено в роботі [10]):

1. Суттєве підвищення енергоефективності та енергозбереження («сценарій енергоефективності»). Завдяки цьому потреба СС в енергії у 2050 році має знизитись приблизно на $40 \%$ порівняно з піком 2005...2006 років.

2. Суттєве підвищення частки відновлюваних джерел енергії в енергобалансі («сценарій
ВДЕ»). В результаті цього частка ВДЕ в кінцевому енергоспоживанні має досягти $75 \%$, а у споживанні електроенергії - 97 \% в 2050 році.

3. Диверсифікація джерел енергопостачання. В даному сценарії перевага не надається жодному джерелу енергії, всі вони конкурують між собою на ринкових засадах. Декарбонізація в даному випадку буде досягнута шляхом впровадження відповідної податкової політики щодо обсягів викидів вуглецю.

Розглянуто також дві варіації цього сценарію:

4. Диверсифікація джерел енергопостачання 3 відстроченим впровадженням технологій уловлювання і зберігання вуглецю. 


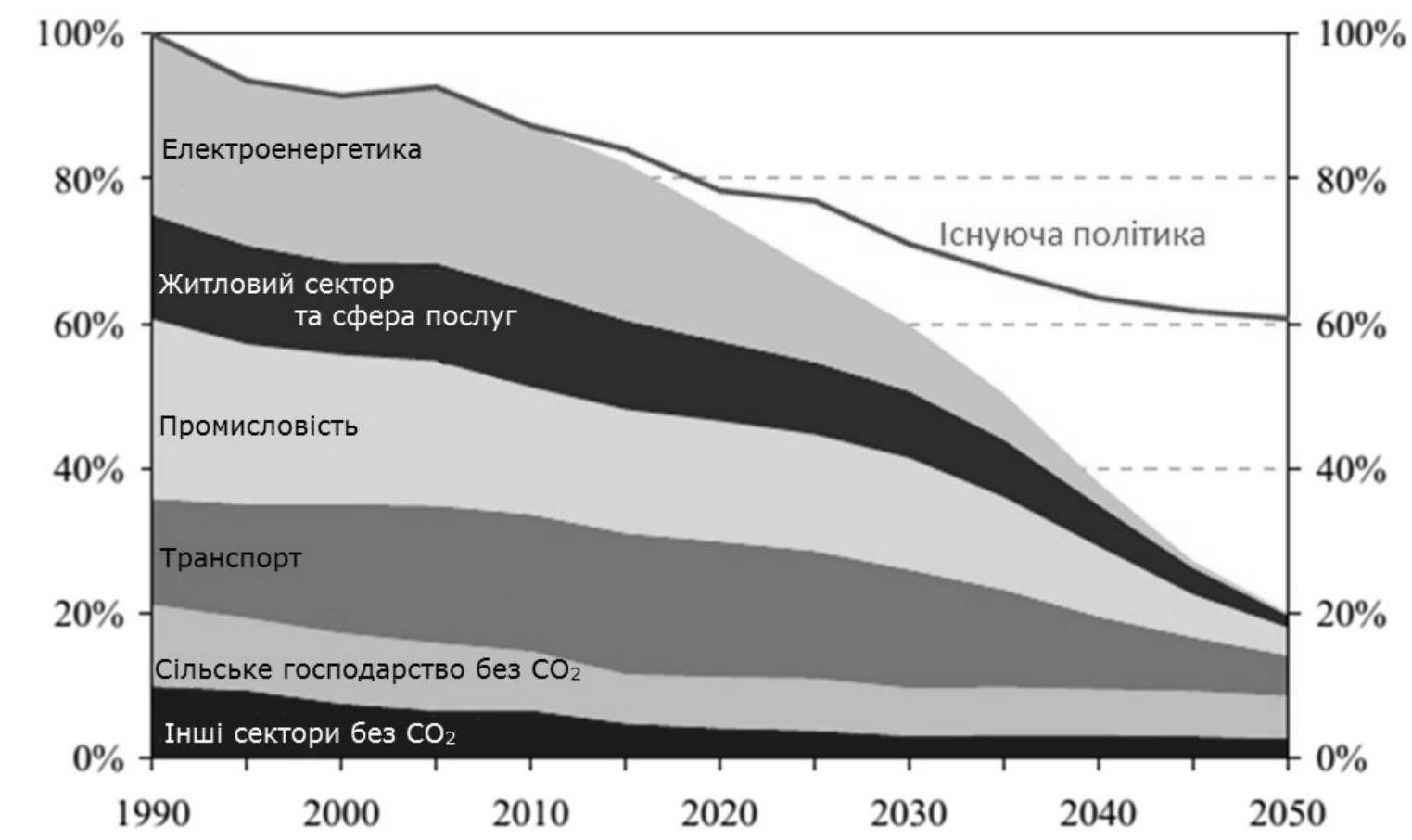

Рис. 6. Стратегія скорочення викидів парникових газів в СС до 2050 р. на 80 \% порівняно з 1990 р. відповідно до зобов'язань урядів краӥн-членів СС [8].

5. Диверсифікація джерел енергопостачання за умови, що нові атомні блоки не будуть споруджуватись, окрім тих, що будуються вже зараз.

Варто зазначити, що «сценарій ВДЕ» непогано узгоджується 3 прогнозом перспектив розвитку енергетики $\mathrm{CC}$, виконаним Європейською радою з ВДЕ [11]. Цей прогноз показує реальну можливість покриття потреби СС в енергії у 2050 році майже на $100 \%$ за рахунок відновлюваних джерел, в тому числі біомаса - $34 \%$, сонячна енергія - $26 \%$, геотермальна енергія 17 \%, енергія вітру - $13 \%$, решта $(6 \%)$ - інші ВДЕ. При цьому кінцеве енергоспоживання у 2050 р. (1050 млн. т н.е.) має скоротитися на 12 \% у порівнянні з 2020 р. (1200 млн. т н.е.).

\section{Висновки}

Загроза глобального потепління, вичерпність викопних палив та інші виклики сучасності змушують країни світу суттєво змінювати структуру енергетичного сектору. Наразі можна спостерігати дві основні тенденції - заміну традиційних енергоносіїв відновлюваними джерелами енергії та скорочення загального енер- госпоживання за рахунок впровадження енергоефективних технологій та заходів. Все більше країн розробляють і реалізують плани та стратегії для значного, в межах 50..100 \%, покриття своїх енергетичних потреб за рахунок відновлюваних джерел енергії.

\section{ЛІТЕРАТУРА}

1. Energy technology perspectives 2012. Pathway to a Clean Energy System. IEA, 2012. https://www.iea.org/publications/freepublications/ publication/ETP2012_free.pdf

2. Renewables 2015. Global Status Report. REN21, 2015.

http://www.ren21.net/status-of-renewables/globalstatus-report/

3. REmap 2030: A Renewable Energy Roadmap, IRENA, 2014.

http://www.irena.org/remap/IRENA_REmap_ Report_June_2014.pdf

4. World Energy Scenarios. Composing energy futures to 2050. WEC, 2013.

https:/www.worldenergy.org/wp-content/uploads/ 2013/09/World-Energy-Scenarios_Composing- 
energy-futures-to-2050_Full-report.pdf

5. Go $100 \%$ Renewable Energy project. http://www.go100percent.org/cms/index.php?id=19 2015.

http://www.eurobserv-er.org/pdf/press/2015/EurObservERPress-Release-Estimates-of-the-renewable-energy-2015. pdf

7. Krzysztof Gierulski. Energy Efficiency Indicators in the EU Energy Efficiency Directive. Презентація на семінаріПРООН, Київ, 13.10.2015.

8. A Roadmap for moving to a competitive low carbon economy in 2050. COM(2011) 112 final, 8.3.2011

http://eur-lex.europa.eu/resource.html?uri=cellar: 5db26ecc-ba4e-4de2-ae08-dba649109d18.0002.03/ DOC_1\&format $=$ PDF

9. Energy Roadmap 2050. $\operatorname{COM(2011)~} 885$ final, 15.12.2011.

http://eur-lex.europa.eu/legal-content/EN/TXT/PDF /?uri $=$ CELEX:52011DC0885\&from $=\mathrm{EN}$

10. Гелетуха Г.Г., Желєзна Т.А., Дроздова О.І. Аналіз основних положень Дорожньої Карти $Є С$ з енергетики до 2050 року // Промислова теплотехніка. - 2012, Т. 34, № 6. - С. 64-69.

11. RE-Thinking 2050. A $100 \%$ Renewable Energy Vision for the European Union. EREC, 2010. http://www2.warwick.ac.uk/fac/soc/csgr/green/ foresight/energyenvironment/2010_erec rethinkhing_2050.pdf 


\section{ANALYSIS OF ENERGY STRATEGIES OF EU AND WORLD COUNTRIES AND THE ROLE OF RENEWABLES IN THE STRATEGIES. PART 1}

Geletukha G.G., Zheliezna T.A., Bashtovyi A.I.

Institute of Engineering Thermophysics of the National Academy of Sciences of Ukraine, vul. Zhelyabova, 2a, Kyiv, 03680, Ukraine

The paper covers state of the art and prospects for the development of renewable energy in the world and in the European Union. Energy strategies and forecasts for the energy sector development until 2050 are analyzed. It is shown that the threat of global warming, the fact that fossil fuels are exhaustible and other challenges of the present time force countries to change the structure of energy sector significantly. Now one can observe two basic tendencies, namely replacement of fossil fuels by renewables and reduction of the total energy consumption at the expense of introduction of energy efficient technologies and energy saving measures. More and more countries are developing and implementing plans and strategies for considerable, up to $50 \ldots 100 \%$, covering energy demand at the expense of renewable energy sources. At the same time, they act appropriately on reducing consumption of primary energy.

References 9, tables 1, figures 6.

Key words: renewable energy sources, renewable energy, final energy consumption, energy efficiency, greenhouse gases

1. Energy technology perspectives 2012. Pathway to a Clean Energy System. IEA, 2012.

https://www.iea.org/publications/freepublications/ publication/ETP2012_free.pdf

2. Renewables 2015. Global Status Report. REN21, 2015. http://www.ren21.net/status-of-renewables/globalstatus-report/

3. REmap 2030: A Renewable Energy Roadmap, IRENA, 2014.

http://www.irena.org/remap/IRENA_REmap_ Report_June_2014.pdf

4. World Energy Scenarios. Composing energy futures to 2050. WEC, 2013.

https:/www.worldenergy.org/wp-content/uploads/2013/ 09/World-Energy-Scenarios_Composing-energyfutures-to-2050_Full-report.pdf

5. Go $100 \%$ Renewable Energy project. http:// www.go100percent.org/cms/index.php?id=19 2015.

6. EurObserv'ER press release of December http://www.eurobserv-er.org/pdf/press/2015/EurObservERPress-Release-Estimates-of-the-renewableenergy-2015.pdf

7. Krzysztof Gierulski. Energy Efficiency Indicators in the EU Energy Efficiency Directive. Presentation at UNDP seminar, Kyiv, 13.10.2015.

8. A Roadmap for moving to a competitive low carbon economy in 2050. $\operatorname{COM}(2011) 112$ final, 8.3.2011

http://eur-lex.europa.eu/resource.html?uri=cellar: 5db26ecc-ba4e-4de2-ae08-dba649109d18.0002.03/ DOC_1\&format $=$ PDF

9. Energy Roadmap 2050. COM(2011) 885 final, 15.12.2011.

http://eur-lex.europa.eu/legal-content/EN/TXT/PDF /?uri=CELEX:52011DC0885\&from $=\mathrm{EN}$

10. Geletukha G.G., Zheliezna T.A., Drozdova O.I. Analysis of main points of the EU energy roadmap 2050 // Promyshlennaya teplotekhnika. - 2012, V. 34, N 6. - P. 64-69. (Ukr.)

11. RE-Thinking 2050. A $100 \%$ Renewable Energy Vision for the European Union. EREC, 2010. http://www2.warwick.ac.uk/fac/soc/csgr/green/foresight/ energyenvironment/2010_erec_rethinkhing_2050.pdf

Получено 11.01.2016 Received 11.01.2016 